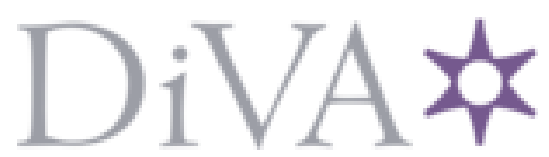

http://www.diva-portal.org

\title{
Postprint
}

This is the accepted version of a paper published in Language and Dialogue. This paper has been peerreviewed but does not include the final publisher proof-corrections or journal pagination.

Citation for the original published paper (version of record):

Lundin, B. (2013)

Dialogue features in football articles over a period of fifty years.

Language and Dialogue, 3(3): 402-420

http://dx.doi.org/10.1075/ld.3.3.04lun

Access to the published version may require subscription.

N.B. When citing this work, cite the original published paper.

Permanent link to this version:

http://urn.kb.se/resolve?urn=urn:nbn:se:hj:diva-22574 


\section{Dialogue features in football articles over a period of 50 years}

Barbro Lundin

University of Learning and Communication, Jönköping

In this diachronic study of dialogic features in football, articles from three different sports events have been focused: The World Cups 1958, 1974 and the Euro Cup 2004. This period of almost 50 years distinguishes itself as a time period when new channels for communication have emerged: television, Internet, computer-mediated communication. This has made it possible to bridge the gulf between the communicators. Dialogue features such as questions, directives, addressing the readers with you (second person singular) and using an inclusive we are numerous in the football articles studied. The articles show an increasing tendency to address the readers with you in the articles from Euro 2004. Moreover, the sports writers refer to given responses from readers in the articles from 2004.

Keywords: dialogue, discourse, feedback, sports journalism, speech acts, colloquialization

\section{Introduction}

The language used in commenting on sports in media has been the topic of some research over the last decades (Beard 1998; Boyle 2006; Delin 2000; Lavric et al. 2010; Wenner 1989). In all research on media the impact of factors surrounding the texts - ideologies, social practices and values cherished by society - are highlighted as important (Beard 1998; Fairclough 1995; Fairclough and Wodak 1997; Fairclough 2001; Wenner 1989). While sports has been seen as "light material", comparable to entertainment in media, there is little doubt that it nevertheless is imbued with prevailing values in society, though the impact may prima facie not be so salient as in other fields of media. Sports has been regarded as "safe" material, challenging no political ideologies, but rather defending the status quo in society (Boyle 2006; McChesney 1989).

'Media' is a broad concept that includes channels for both spoken and written communication. The spoken language in broadcast media and on Internet has, not 
surprisingly, been focused in media research (e.g. Delin 2000; Fairclough 2001; Gerhardt 2010; Jung 2010) being new channels for communication, mostly representing a more casual, informal style in language use, more in line with a natural dialogue between equals than a "top-down" kind of communication.

Weigand $(2006,2010)$ has highlighted the dialogic character of communication in a theory called The Mixed Game Model. It describes human beings as involved in a dialogue with a real or presumed interlocutor. The purposes of this dialogue, or (communication) game as it is called, can vary, and the formal structure of utterances, locutions with a term from Austin's speech act theory (1975), does not always coincide with the illocutive speech acts. This is obvious in an analysis of any exchange of utterances in a dialogue (more about this below). In the dialogue we exchange different types of utterances, and sometimes misunderstandings will arise, but mostly we negotiate with the interlocutor to arrive at some level of mutual understanding. As Weigand puts it: "Language is primarily used for communicative purposes [and c] ommunication is always performed dialogically" $(2009,23)$. While most analyses within this framework are based on the spoken language, or written genres that are close to the spoken language (e.g. Internet Relay Chats), the principles that constitute human interaction, presented by Weigand, are also relevant to the written language, all the more in a context where the presumptive readers of the texts are concerned as laymen experts. The minimal units of the dialogue are actions and reactions from the interlocutors.

According to this theory, the sports writer's feature would be seen as actions of different kinds, which will be met by some reaction from the reader, though this is not evident from the text itself. There is however always the possibility to integrate a possible reaction from the reader into the text, which occurs now and then.

A hybrid form between spoken and written language, is the 'computer mediated communication' (CMC) that is used in newspapers' online commentaries on games like football (Chovanec 2010; Gerhardt 2010; Pérez-Sabater et al. 2008). The language used in these minute-by-minute-commentaries is described as being more informal than in ordinary genres of written language, containing taboo words, contracted forms and incomplete sentences.

The colloquialization of public discourse (Leech et al. 2009) over the last centuries has been acknowledged in research on newspaper langugage (Bell 1991; Ljung 1996; Westin 2008; Söderblom 2002). The written language in different genres of newspaper prose has approached oral language in a number of ways, such as more informal alternatives of word 
forms (Ljung 1996), use of informal vocabulary (Bagnall 1993; Ljung 1996), and the broken forms of syntax or short sentences (Biber 1989; Biber and Finegan 1989; Westin 2002). This tendency is also expressed in the way information and standpoints are presented, emulating a kind of dialogue where the readers are on the surface involved (v. Dijk 1997; Fairclough $2001,72)$. A statement about the play in a football game is sometimes followed by a question mark, indirectly prompting the reader to agree or disagree. Modern technology has made dialogue more accessible to the receivers, though this dialogue is not equal to a face-to-face dialogue. The author is the one who decides what to dwell on and how to estimate the achievements in the field. The sports writers' role in this kind of dialogue can be compared to the presenters' role in broadcast media - either as an expert on the topic, or as a representative of the audience, who asks the questions that the listener/reader would ask in an everyday conversation.

The dialogic approach, that the new media have brought about, has also contributed to a closer relationship between author and readers in print media. The readers can more easily than before give feedback to the writings in the newspapers through email, even if few readers are likely to make use of these possibilities (Bell 1991, 12; v. Dijk 2006). The use of sentences expressing different illocutionary speech acts in newspapers has so far not been focused in research on newspaper or media language, though questions, imperatives and statements are part of some research on media language by e.g. Biber (1989), Fairclough (1995) and Westin (2008). These features are usually interpreted to express involvement from the writer's side. I will describe this aspect of the language in depth here and disregard other language features that also contribute to this confidential dialogue style that $I$ have found in sports commentaries. I will describe how these dialogic features in the form of directives or questions ('exploratives' in Weigand's model) are used to involve the readers in the dialogue. The material I have based my study on consists of written texts from different events, not face-to-face-situations, where a speaker and an interlocutor exchange actions and reactions. I will focus on some conspicuous traits in the football articles that indicate dialogic tendencies, such as sentences containing directives and questions, in accordance with terms used in authoritative grammars like Quirks et al. (1985). I will discuss the illocutionary force of directives and questions from a contextual perspective. On the surface the writers of these articles are acting independently from any interlocutor, but of course they are highly aware of the possible reactions from the presumptive readers. 
Fairclough $(1995,9)$ has coined the term conversationalization for the tendency to address the audience more directly and to use a more casual language associated with everyday language than was customary earlier. This style can be used to make the audience believe they are more equal to those in power than they actually are, he argues. The type of discourse used in modern media in some Western societies tends to emulate a more egalitarian and even intimate dialogue between the speaker/interviewer and the audience/interviewee than used to be considered correct some decades ago (Fairclough and Wodak 1997). In Sweden, the use of $d u$, the second person singular pronoun, to address one person (equivalent with $t u$ in French) regardless of status or age has long been considered correct, some journalists will even now and then use this word of address to members of the royal family, though this is generally not considered respectful enough.

The tendency for prominent people to fraternize with the audience in media has been described by Fairclough and Wodak $(1997,274 f)$ in their analysis of how Mrs Thatcher in a TV interview used you and inclusive we to imply she was an ordinary person just like the voters. This familiarity with the audience is noticeable in some genres of newspaper language, and very much so in the sports articles that I have studied.

Sports journalism has, generally speaking, not enjoyed a high reputation among those who are occupied in other fields of media (Rowe 1995, 159, referred to by Boyle 2006, 17). This lowly position is arguably reflected in the scarce representation of sports journalism in media research and in the education of journalists (Boyle 2006, 7). On the other hand, this has had the positive consequence that sports writers have greater license to write in a more colourful and personal way (McChesney 1989). Features that contain analyses about the football game are often adorned by literary citations, word games and peculiar metaphors (Chovanec 2008a, 2008b).

The von oben attitude to sports seems however to have changed, since even quality papers like The Times nowadays are investing a lot of prestige in their coverage of sports (Boyle 2006, 51f). While sports used to be associated to entertainment and hobbies, it has over the last decade or so been appreciated as something that concerns nearly all aspects of society, appealing increasingly to more well-educated and affluent people than earlier.

Football (sometimes called soccer in e.g. the US) is the sport that for a long time has been the most cherished one by the media, since it is practiced all over the world and seems to have attracted more fans than any other sport. The space devoted to football in print and broadcast media dominates greatly over other sports. The writers of football features often strike a 
familiar note in their articles, presuming that the readers have about the same experiences and above all the same passion for football. This friendly note is manifested through the use of questions and directives that he (the sports writers are almost exlusively men) puts to the readers, the tendency to address the reader or include him/her in the circle of sports fans. The readers are so to say included in a dialogue over the play on the football field.

\section{Purpose}

It is my ambition to answer the following questions:

To what extent do the writers of football articles over the last five decades use dialogic features in their way of writing, by using different illocutionary speech acts (questions or directives) and addressing the audience with the second person pronouns, inclusive we or by referring to responses from the readers?

Is this tendency to use dialogue features, which may result in a response from the readers, more pronounced in sports commentaries from 2004 than in 1958 and 1974? What differences are there and how can they be explained?

\section{Material}

Table 1: Newspapers and events covered in the material

\begin{tabular}{lll}
\hline Newspapers & Event - year & $\begin{array}{l}\text { Quantity: number of } \\
\text { words in 20 articles }\end{array}$ \\
\hline Aftonbladet & World cup 1958 & 10355 words \\
Aftonbladet & World cup 1974 & 11370 words \\
$\begin{array}{l}\text { Aftonbladet, Expressen, Dagens Nyheter, } \\
\text { Svenska Dagbladet, Sydsvenska dagbladet }\end{array}$ & Euro 2004 & 11880 words \\
\hline
\end{tabular}

The time period studied stretches from 1958 till 2004, that is almost 50 years. I chose years, where it could be expected that the interest for the game (in media) would be particularly high because of such events as World or Euro cups. To find material from the World Cups in 1958 and 1974 I have had to use microfilms containing photocopies of the journals, a not very convenient way of studying the language, due to the sometimes poor quality of copied texts from the microfilm machines. I chose to examine one of the most widely distributed 
newspapers - Aftonbladet - from the years 1958 and 1974 in the period of June-July, when the World Cup of Football was going on.

The football commentaries from the Euro 2004 were easily retrieved, partly in paper form and partly from the databases Mediearkivet and Presstext. From this event, I have, besides Aftonbladet, collected articles from the tabloid Expressen and the broadsheets Dagens Nyheter, Svenska Dagbladet and Sydsvenska Dagbladet.

I have focused on articles that consist of expert commentaries on a certain match during the World Cup, not necessarily games where the Swedish team was involved, though most of them are. The articles commenting on the prospects for the Swedish team to be successful in the Cup or those about a certain match that the Swedish team had played, are those that seem to be the most elaborated ones, written by the most authoritative sports writers. Articles which for the larger part consist of interviews with players or coaches have been excluded.

Aftonbladet and Expressen are the two largest evening newspapers in Sweden (and in Scandinavia). Both newspapers are tabloid papers, with about 1.500000 copies per day. Aftonbladet is described as "independent social-democrat" and Expressen as "independent liberal". They have about the same layout and image as tabloid papers, focusing more on scandalous events and celebrities than "heavy" features on culture and politics. Both papers have a special supplement devoted to sports alone. Most people who are passionately interested in sports choose to read the sports articles in either of these two papers, though all newspapers nowadays give quite good space for sports, particularly great events like World and Europe Cups.

Dagens Nyheter, Svenska Dagbladet and Sydsvenska Dagbladet are morning papers, the two first mentioned are published in Stockholm and are widely distributed all over the country, the third is published in Malmö (the third largest city) and is mainly distributed in the southernmost parts of Sweden. They are all identified as "independent liberal" politically. Nowadays they have the size of tabloids, while up to some years ago they were distributed in the size of broadsheets.

The journalists who wrote the articles studied are for the most part well-known sports writers, who regularly wrote/write features about football. The authors of the articles from 1958 and 1974 are few, since they represent only one newspaper - Aftonbladet. In fact the majority of the articles from these years were written by two journalists. 


\section{The sporting events in 1958,1974 and 2004}

In 1958 most Swedish families had just invested in a TV-set (black-and-white), which made it natural for the sports writer to refer to the visual impressions that the readers might have had. Earlier they had had to listen to the commentaries on the radio sets, if they did not have the opportunity to be present at the venues where the matches were played. In 1958 the World Cup was held in Sweden, which made it easier for Swedish football fans to be on the spot where it happened.

In 1974 the World Cup was held in Germany, which is not too far away for Swedish fans to visit, though most of them followed the matches on TV. By now most Swedes had acquired a colour TV set.

In 2004 the Euro was held in Portugal. By then Internet and computer technique were commonly used in all media settings. This made the communication between writer and readers of newspaper texts still more accessible to the readers, since they now could respond per email to standpoints expressed in the articles. References to this communication can be expected to be seen in the articles about football.

\section{Method}

I have restricted my study to 20 articles per event to make the comparison between the three different events justifiable, though in the case of the Euro 2004 the material was widely more accessible, and the total material is of course much more comprehensive than that accounted for in this study.

My focus has been directed to the sentence types of two different illocutionary speech acts: questions and directives. In speech act theory, which has been presented by above all Austin (1975) and Searle (1969), utterances are described from the perspective of what we do when we say something. The important thing here is the illocutive dimension, i.e. whether the utterance can be interpreted as a statement, directive or question. Weigand has expanded this theory of dialogue to cover a more complex variety of situations in dialogue. Her theory also makes allowances for rhetoric devices in language, which generally have the purpose to make the interlocutor adhere to the speaker's opinion $(2009,129 \mathrm{ff})$.

I will describe the syntactic form of the different directives or questions (exploratives) since this may add to the overall illocutionary force of the directives or questions. 
In Weigand's theory of the Dialogic Game in language, questions are named exploratives, where the reaction usually is answer, and directives are followed by the reaction called consent.

Furhermore addresses of the readers with you ( $d u$ or $n i$ in Swedish) and references to given feedback from readers have been accounted for. I have categorized the different questions, directives and addresses in subgroups that I found relevant to my issue. The terms used are those that are found in Quirk et al. (1985).

Each article consists mainly of commentaries on a certain match from a sports writer, but in some cases the articles contain quotations from players or coaches. Those quotations have of course been excluded from the account of dialogue features. I will use the phrase sports writer (or just writer) for the journalists who wrote the articles studied. This noun phrase is used by Boyle (2006) to denote those who write articles consisting of analyses, reflections around the game, unlike the 'sports correspondents' who for the most part only quote what players or coaches have said.

I have examined the articles thouroughly with respect for ways to involve the readers in a kind of dialogue, which I henceforth will call dialogue features.

\section{Dialogue features}

According to Austin's Speech Act Theory (1975) uterances can be divided into different categories dependent on the illocutionary speech act that applies to the utterance (referred to in Quirk et al. 1985, 804f). The four main categories of speech acts referred to by Quirk et al. are statements, questions, directives and exclamations. While most statements, questions, directives and exclamations are syntactically and semantically matching, the context can make the illocutionary force in the utterances ambiguous or converse to its syntactic form. A directive can for example be made in the form of an imperative, Shut the door!, which is supposed to be the most regular form, in the form of a question Can you shut the door, (please)? or in the form of a statement You can shut the door.

In Weigand's Dialogic Theory the directives are divided into the following three subgroups: direct (Close the window), indirect (Can you close the window) and idiomatic (When are you going to close the window?) $(2009,28)$. In written language a statement can be followed by a question mark to indicate that the claim to truth is unsecure. 
In Critical discourse analysis (CDA) the different ways of saying the same thing may be treated as an issue of power relationship between the speaker and the addressed person (van Dijk 1997; Fairclough 2001). I will in this article not use this power approach in analysing the dialogue features in the football articles. I will rather analyse the tendency to address the readers in different ways as a way to fraternize with the readers, whereby the text is supposedly made more enjoyable for the reader. Weigand's theory about the inherent dialogue of all langue seems reasonable to explain this type of communication, even if it is conducted under different conditions compared to a spoken context. The writer is of course the dominant partner in this dialogue, not likely to subdue to critical opinions to his views about the football achievements from the presumptive partner/reader. Or maybe he/she is? We do not know what influcence the potential interlocutor has (had) on the design of the article.

\subsection{Questions (Exploratives)}

Questions can be made in different ways, using on the surface different types of sentences or just elliptic phrases consisting of one or a few words. The following types of questions will be referred to in this article:

a) Questions that are syntactically marked by a special word order, in the Swedish language by putting the finite verb at the first position, in English by do-constructions, for example Gjorde vi en bra match? (Did we do a good game?). Such questions may sometimes be called rhetoric questions, implying they are a rhetoric trope used mainly to elicit interest from the listener/reader, not intended to be followed by an answer. The rhetoric questions are semantically assertions (Quirk et al. 1985, 825). They are designed to arouse emotions with the listener/reader. There is of course no clear dividing line between the rhetoric questions and "regular" questions, since it is highly dependent on the context and the interpretation of this context. In these texts most questions have been interpreted as "regular" questions since they mostly are followed by reasoning answers.

b) Questions that are syntactically declaratives or elliptic phrases, but ortographically marked as questions by question marks. Example: Så nu är vi säkert i finalen? (So now we will certainly be in the final round?). The question marks indicate that the statements are uncertain propositions and will always be followed by propositions that unravel the uncertainty. In this discourse they might be directed to the readers so as to boost their involvement. 
c) Echo-questions, syntactically marked as indirect wh-questions or dependent clauses beginning with an interrogative pronoun or the subjunction om (if). These questions are typical for a dialogue where one of the partners wants to get a clarifying answer: Vem som spelade bäst? (Who played the best game?) In the indirect wh-question the subject vem (who) is always followed by the subjunction som, unlike the case in direct questions. (Frågade du) vem som borde ha fått gult kort? ([Did you ask] who should have had a yellow card?) Cf direct question: Vem borde ha fätt gult kort? In English this difference is not visible.

The echo-questions can be either recapitulatory or explicatory (Quirk et al. 1985, 835f). The first mentioned is made to repeat something in the previous utterance that seems absurd or unexpected, the second one asks for the clarification rather than the repetition of something just said.

d) Tag questions. These are phrases like Eller hur or Inte sant at the end of a sentence (in English equivalent to e.g. aren't they, isn't she), These phrases make in most cases the statement more unsecure. In a discourse they rather ask for the other partner's opinion: Do/Don't you agree? The purpose is to elicit a confirming answer from the reader(s). Tag questions are more common in spoken usage than in informal written language.

\subsection{Directives}

Directives can be phrased in different ways, some of which are relevant in this study.

a) The directives can be made to either the readers, the players or some other actor in the game. Directives as a speech act are normally characterized by a special verb form imperatives - and a special word order, where the finite verb always comes first in Swedish: Kom nu (Come now), sometimes the imperative form is identical with the infinitive (as in English), Tala högt (Speak loudly). Graphically a directive is often marked by an exclamation mark: Titta noga på hur Chippen sparkar bollen! (Follow closely how Chippen kicks the ball!).

b) A directive can also be put in a more indirect, elliptic way, using no verb at all: More water! equal to a full sentence (Give me more water!), No sour faces! (Don't show any sour faces!) This type of directives might even be more common than the regular directives using an imperative. 


\subsection{Addressing the reader with you and using an inclusive we}

In Swedish the pronoun $d u$ is commonly used to address even an unknown person, though $n i$ is still used by chiefly younger persons to noticeably older persons they do not know. The $d u$ reform in the sixties meant an approach to the mainstream egalitarian ideology in society that was gaining ground. Among most Swedes this casual way to address other people was considered comfortable. Over the last two decades there seems to have been a relapse into the use of $n i$ to an unknown and noticeably older person among young people (Norrby 1997). It could be argued that the use of $d u$ or $n i$ might reflect a more or less respectful attitude to the readers from the author's perspective. It is however difficult to know whether the writer uses the pronoun $n i$ to indicate a more polite attitude to one reader (as a representative of all readers), or if the pronoun is used to address all the presumptive readers, since the finite verb in Swedish has no endings that indicate number.

The use of we contributes to the tone of matey discourse between football freaks, mostly used to invoke a feeling of community, togetherness. I have of course included the object form of we (oss) and the corresponding possessive pronoun our in this category.

The different types of dialogue features may of course be combined in one single utterance: Tycker ni att grabbarna gjorde dåligt ifrån sig igår? (Do you think that the lads played badly yesterday?) In these cases I have included them in both the group of questions and the group of addressing the readers.

\subsection{Responses to given responses from readers}

Yet another form of including the readers in the commentary is referring to some of them in the third person: "Greeks are mailing me about my comments on the Greek team play [...]" This phenomenon - giving feedback to response- is an evidence for the writer's sensitiveness to the views from his readers, and his ambition to make the communication interactive (Schultz 1999). Readers are often encouraged to give their opinions of the contents at the end of an article, where they find the email-address to the writer. 


\section{Results}

In table 2 the number of articles that contained dialogue features represent the overall existence of any question, directive or address with you, or use of inclusive we, not the total number of questions and so forth in all the articles. If all the occurrences of dialogue features had been counted the tendencies would have been stronger, since in some cases the sport writer directs himself to the readers throughout the article.

Table 2: Number of articles in newspapers from 1958, 1974 and 2004 that contain dialogue features. Total number of articles each year: 20

\begin{tabular}{lccc}
\hline & World Cup 1958 & World Cup 1974 & Euro 2004 \\
\hline Questions & 9 & 8 & 6 \\
Directives & 4 & 4 & 6 \\
Addresses of the readers, you - we & 5 & 4 & 8 \\
References to the readers' responses & 0 & 0 & 4 \\
Total & $\mathbf{1 8}$ & $\mathbf{1 6}$ & $\mathbf{2 4}$ \\
\hline
\end{tabular}

\subsection{Questions}

The questions are quite evenly distributed between the three events. The tendency to involve the reader in this way is not more salient in any one of the three events, though the sports writers in 1958 used somewhat more questions. The number of articles with one or more questions are nine in 1958 and somewhat fewer in the later sporting events. A close reading of the articles shows that the sports writers have used questions of different kinds, whether these questions are "regular" questions, rhetoric questions, echoe questions or tag questions.

\subsubsection{Regular questions followed by answers}

The questions used are of a kind that a partner in a conversation would ask - the reader of the article - and the sports writer gives a response to that presumed question. In some cases, as in the last example below, the question is formed as a declarative sentence.

(1) Vilka var det bästa laget i detta VM? Jag ville besvara denna fråga med "jaså”. Who were the best team in this World Cup? I would prefer to answer this question with an "Oh?". (Aftonbladet 1958)

(2) Var ligger finessen med det? Jo, man vill skapa ett intryck av att Västtyskland slår ur underläge. What's the point of that? Well, you want to make the impression that West Germany is hitting from an inferior position. (Aftonbladet 1974) 
(3) Beckham? Ja, så där. Klok, elegant förspel till Englands 1-0-mål. Beckham? Well, quite good. Wise, elegant foreplay leading to England's 1-0-goal. (Sydsvenska Dagbladet 2004)

(4) Så nu är vi europamästare? Knappast. So now we are Euro 2004 winners? Hardly. (Expressen, 2004)

\subsubsection{Rhetoric questions}

Very few, only two questions, have been interpreted as rhetoric questions. In these cases one could not expect anyone to respond in any other way than confirming the view expressed in the question. They are easily converted to an emotive assertion (see example 5 below) like "Gren and Liedholm are indeed capable of doing wonderful things when they are at their best."

(5) Vad kan inte vi få uppleva, när Gren och Liedholm är RIKTIGT sig själva? Dom var det inte $i$ går, och ändå [...] What could we not see when Gren and Liedholm REALLY are themselves? They weren't yesterday and still [....] (Aftonbladet, 1958)

(6) Kan man begära mer? Could you ask for more [than a fifth placement for Sweden]? (Aftonbladet 1974)

\subsubsection{Echo questions}

The two echo questions in the material, which are of the clarifying kind, make a vivid impression of a fictive dialogue that is going on.

(7) Vad den ryske spionen $i$ Uddevalla rapporterat? What the Russian spy in Uddevalla has reported? (Aftonbladet 1958)

(8) Vilket lag som vinner? Which team will win? (Svenska Dagbladet 2004)

\subsubsection{Tag questions}

The two examples of tag questions were found in the articles from 1974, both produced by the same sports writer (Nic Åslund), which may be a stylistic quality typical for him.

(9) Men nog är det motigt om en VM-final avgörs på en feldömd straff, eller hur? Certainly it is untoward if a World Cup is settled by a wrongly judged penalty, isn't it? (Aftonbladet 1974)

(10) En match mellan två representanter för den moderna offensiva skolan vore inget dåligt surrogat, eller hur? A match between two representants of the modern offensive school would be no bad surrogate, would it? (Aftonbladet 1974) 


\subsection{Directives}

The sports writer may turn themselves to different actors around the game with directives, not only the readers, but quite often to the coaches of the national team, or even to individual players with direct directives or advice about the team composition or the strategy. The directives are constructed with imperatives in some cases:

(11) Till slut: UK, "experimentera" gärna mot Wales Finally: UK ${ }^{\mathrm{i}}$ make 'experiments' against Wales, please. (Aftonbladet 1958)

(12) Var INTE fega nu, kaptener! DON'T be chicken now, coaches ${ }^{\mathrm{ii}}$ (Aftonbladet, 2004)

(13) Nyp er i armen - det är sant. Pinch your arms - it's true! (Aftonbladet 1974)

(14) Ställ in skärpan extra noga på TV i eftermiddag! Sharpen the focus of your TV-sets extremely well this afternoon! (Aftonbladet 1974)

(15). Njut av ögonblicket! Njut av sagan om Henrik Larssons comeback! Enjoy this moment! Enjoy the fairytale about Henrik Larsson's comeback! (Aftonbladet 1974)

In most cases, however, the directives are put in a more indirect way, using exclamation marks, or by putting the name of the addressed player(s) at the end of the sentence.

(16) Dags att visa lite stake, Beckham. Time to show some hard-on, Beckham! (Dagens Nyheter, 2004)

(17) Oavgjort tack, det räcker! Draw - please, that's enough! (Aftonbladet June 1974)

(18) [....] Ja då ska ni öppna era korpgluggar framför TV:n i kväll!!! [... ] well, then you should open up your eyes wide while watching TV this evening!!! (Aftonbladet 1974). 


\subsection{Addressing the readers/coaches/players with you or use of inclusive we}

Table 3. The use of $d u$ and ni (you to one or more persons), inclusive we and references to readers' responses

\begin{tabular}{llll}
\hline & World Cup 1958 & World Cup 1974 & Euro 2004 \\
\hline$D u$ (you sing.) & 0 & 0 & 3 \\
$N i$ (you plur.) & 3 & 12 & 1 \\
$V i$ (we) & 3 & 6 & 9 \\
$\begin{array}{l}\text { References to } \\
\text { responses from }\end{array}$ & 0 & 0 & 4 \\
readers & & & \\
Total & $\mathbf{6}$ & $\mathbf{1 8}$ & $\mathbf{1 7}$ \\
\hline
\end{tabular}

In some cases the writer turns directly to the readers to express the we-feeling - all us that are interested in football - or just - we the Swedes. The writer indicates hereby that the whole nation is behind the football team during the Cup.

(19) Ni såg kanske hur han trollade med bollen igår. Vi led med våra gubbar. You might have seen the way he made magic with the ball yesterday. We were suffering with our lads (Aftonbladet 1958)

(20) Den vidunderliga Tomaszewski - ni vet målvakten som "slog" England med 1-1 i VM$k v a l e t$ - tog den. The marvellous Tomaszewski - you know the goalkeeper who "beat" England by 1-1 in the qualification match for the World Cup - took it. (Aftonbladet, 1974)

(21) Och vi, vi stackars dårar som bara har talang nog för att se på, vi vill naturligtvis se Sverige spela mot de bästa. And we, poor lunatics who just have the talent to watch the game, we want of course Sweden to play against the best players. (Expressen, 2004)

(22) Ni skulle faktiskt inte tro mig om jag berättade. You would never believe me if I told you. (Expressen, 2004)

Sometimes the sports writer conjures up a situation that the reader is supposed to be familiar with. Or he (most sports writers are men) asserts the duty to play good football for "you who are sitting in front of the tv set”.

(23) Du vet hur det är. Du går till stadion, äter en korv, hoppas på tre pinnar-och så släpper idioten till målvakt in 0-1 direkt. You know what's it like. You go to the stadion, eat a sausage, hope for three goals - and then the idiot of a goal-keeper lets in a goal immediately. (Aftonbladet, 2004)

(24) De ska tänka på alla er som sitter hemma framför tv-apparaterna, ... They [the players] should think of all you sitting in front of your teve-sets at home... (Dagens Nyheter 2004) 
When a game has ended in an unexpectedly felicitous way - as was the case in the game between Denmark and Sweden - the journalist comments about it as if it were un unforgettable result that will always be in our, the Swedish people's, mind.

(25) En galnare kväll får vi aldrig igen. --- Det här får vi leva med i evig tid. Om det så i den eviga tiden kommer en istid, och det efter den istiden reser sig en ny värld och den världen brinner ner kommer en Luigi eller Pietro smyga upp bakifrån och skrika: - Due a due?! We will never have a crazier evening. --- This is something we will live with for ever. If it will come to another ice age, and after that ice age a new world will rise and that world will burn down, there will be a Luigi or Pietro sneaking from behind screaming - Due a due?!

(Aftonbladet, 2004)

\subsection{Referring to given response from the reader}

The sports journalists are in a double bind during international sporting events: on one hand they are expected to be impartial in their commentaries about the qualities in the play, to give a matter-of-fact description of good and bad achievements of any team, on the other hand they are expected by many fans to support the national team and to speak well about their chances to progress. Unsurprisingly, they will often get angry commentaries from those who dislike their opinions about any specific player or team. This is most evident in some articles from 2004.

(26) Greker mejlar mig. Sura för att jag inte hyllar deras hjältar. Greeks are mailing me, cross with me beacause I don't cherish their heroes. (DN 2004)

(27) Det är alltid några som menar att vi överskattar våra spelare för att vi är svenskar och [...]. Det är komplett bullshit. There will always be those who say that we overestimate our players because we are Swedes and [...]. Just bullshit! (Expressen 2004)

\section{Conclusions}

My material covering football matches from World cup and Europe cup events in 1958, 1974 and 2004 is not based on a very large sample of texts, so the tendencies studied might not be representative of all articles published, though this is my strong impression from reading a lot more features on football texts. One thing that might bias the tendencies shown, is the fact that these articles have been written by a relatively small number of journalists. This holds especially for the articles from 1958 and 1974 that are based on one single newspaper, Aftonbladet. Journalists have their personal way of writing, using all stylistic devices in 
different ways. This is noticable in the articles from 2004 that were written by one of the journalists who more often than the other journalists gave directives to either the readers or other actors in the football games.

One conclusion from this study is that journalists seem to be aware of the fact that their actions as writers (statements, directives or exploratives) are met by reactions from the readers. Though this is generally not explicitly mentioned in the articles, the contents of the articles give evidence to this fact. Quite often the heading is designed as a directive or a question (explorative). The questions in the articles are generally no rhetoric questions. They are rather the starting-point for the reasoning around the ups and downs in the matches or around the national team as a whole. This is typical for a dialogue between people who are engaged in a discussion. There is no outspoken tendency in my material between the three events concerning the types of questions. The writer seems to have a general dialogue with himself or a presumptive interlocutor while writing his or her text.

The directives are somewhat more frequent in the articles from 2004, in all events they are directed to coaches or players rather than to readers. Declaratives directed to the readers are more of a rethoric kind, not really requesting the reader to do anything. To "pinch one's arms" or "open one's eyes wide" are routine phrases used when something unexpected has happened.

The most salient expression of these fictive dialogues is the addressing of the reader with you (in Swedish $d u$ or $n i$ to address either one or more persons). This makes the fictive dialogue between writer and reader more vivid, involving the reader into the text. This feature is more frequent in the commentaries from 2004. The commentaries to readers' feedback take this dialogic feature one step further. So in Weigand's terms the game between the sender and the addressees follows the pattern of action - reaction which in its turn evokes another action from the sender. The writer shows that he gives attention to the readers' opinions, even if he does not subdue to them. This tendency is slightly more pronounced in tabloid papers like Aftonbladet and Expressen, though it is by no means absent in the "broadsheet" papers Dagens Nyheter, Svenska Dagbladet and Sydsvenska Dagbladet. The personal note is somewhat stronger in the tabloids than in the broadsheets, visible through the use of the first pronoun $-I$, though I have not accounted for this feature in this study.

The tendencies to use dialogic features in the commentaries are, unsurprisingly, more outspoken in the articles from Euro 2004. This tendency is noticeable above all in the numerous addresses of the readers with you or in the use of inclusive we. Furthermore some 
of writers of the sports articles from 2004 make references to the responses they have received from the readers. This is undoubtedly due to the enhanced channels of communication through email and Internet relay chat, often conducted while watching the game on tv.

My study shows that the tendency to conversationalization in media mentioned earlier is noticeable in the dialogue features in the newspapers of today. This is typical of the more informal genres in the newspapers, like the football features.

The idea of having the readers in mind when writing a text, should be a hallmark for all journalism. In the football articles this awareness of the readers' feelings towards and views on the topic is probably stronger than in most other fields of journalism. The discourse of newspaper reports on the football game, especially when the national team is involved, seems to draw a lot on the imagined dialogue between football fans.

\section{Acknowledgements}

I would like to thank the anonymous reviewers of my article for giving me new angles of approach to this subject.

\section{Notes}

i UK stands for "Uttagningskommittén", i.e. a special committee that was collectively responsible for the national football team in the World Cup 1958.

ii There were two coaches for the national Swedish team in 2004.

\section{References:}

Austin, John L. 1975. How to do Things with Words, ed. by J. O. Urmson, and Marina Sbisà. 2nd ed. Oxford: Clarendon.

Bagnall, Nicholas. 1993. Newspaper Language. Oxford: Focal Press.

Beard, Adrian. 1998. The Language of Sport. London and New York: Routledge.

Bell, Allan. 1991. The Language of News Media. Oxford: Blackwell.

Biber, Douglas. 1988. Variation across Speech and Writing. Cambridge: Cambridge University Press.

Biber, Douglas, and Edward Finegan. 1989. 'Drift and the Evolution of English Style: a History of Three Genres". Language 65 (3): 487-517.

Boyle, Raymond. 2006. Sports Journalism. Context and Issues. London: Sage.

Chovanec, Jan. 2008a. "From Zeroo to Heroo: Word Play and Wayne Rooney in the British Press". In Slovak Studies in English I. The Proceedings of the conference organized on the occasion of the 80th anniversary of the opening of British and American Studies at the Faculty of Arts, Comenius University, Bratislava 2005. 85-99. 
Chovanec, Jan. 2008b. "Focus on Form: Foregrounding Devices in Football Reporting". Discourse and Communication 2 (3): 219-242.

Chovanec, Jan. 2010. "Enacting an Imaginary Community: Infotainment in Online Minuteby-Minute Sports Commentaries". In The Linguistics of Football, ed. by Eva Lavric et al., 255-268. Tübingen: Günter Narr Verlag.

Delin, Judy. 2000. "The Language of Sports Commentary." In The Language of Everyday Life, 38-58. London: Sage.

van Dijk, Teun A. 1997. "The Study of Discourse." In Discourse as Structure and Process, ed. by Teun A. van Dijk, 1-34. London: Sage Publications.

Fairclough, Norman. 1995. Media Discourse. London: Edward Arnold.

Fairclough, Norman, and Ruth Wodak. 1997. "Critical Discourse Analysis". In Discourse as Social Interaction 2, ed. by Teun A. van Dijk, 258-284. London: Sage Publications.

Fairclough, Norman. 2001. Language and Power. 2nd ed. Harlow: Longman.

Gerhardt, Cornelia. 2010. "Turn-by-Turn and Move-by-Move: A Multi-Modal Analysis of Live TV Football Commentary". In The Linguistics of Football, ed. by Eva Lavric et al., 283-268. Tübingen: Günter Narr Verlag.

Jung, Kerstin. 2010. "World Cup Football Live on Spanish and Argentine Television: The Spectacle of Language." In The Linguistics of Football, ed. by Eva Lavric et al., 343-358. Tübingen: Günter Narr Verlag.

Lavric, Eva, Gerhard Pisek, Andrew Skinner, and Wolfgang Stadler (eds). 2010. The Linguistics of Football. Tübingen: Günter Narr Verlag.

Leech, Geoffrey, Marianne Hundt, Christian Mair, and Nicholas Smith. 2009. Change in Contemporary English: a Grammatical Study. Cambridge: Cambridge University Press.

Ljung, Magnus. 1997. "The English of British Tabloids and Heavies: Differences and Similarities." In Stockholm Studies in Modern Philology. NS 11:133-148. Stockholm: Almqvist \& Wiksell International.

McChesney, Robert. 1989. "Media Made Sports: A History of Sports Coverage in the United States”. In Media, Sports, \& Society, ed. by Lawrence Wenner, 49-69. London: Sage.

Norrby, Catrin. 1997. "Kandidat Svensson, du eller ni - om utvecklingen av tilltalsskicket i svenskan. [Mr Svensson, $d u$ or $n i$ - the Development of Forms of Address in Swedish]". In Svenska som andraspråk och andra språk [Swedish as a Second Language and Other Languages], ed. by Anders-Börje Andersson, 319-328. Gothenburg University.

Pérez-Sabater, Carmen, Gemma Pena-Martinz, Ed Turney, and Begona Montero-Fleta. 2008. "A Spoken Genre Gets Written: Online Football Commentaries in English, French, and Spanish." Written Communication 25: 235-261.

Quirk, Randolph, David Crystal, and Jan Svartvik. 1985. A Comprehensive Grammar of the English Language. Harlow: Longman.

Rowe, David. 2004. Sport, Culture and Media. Open University Press.

Schultz, Tanjev. 1999. "Interactive Options in Online Journalism: A Content Analysis of 100 U.S. Newspapers.” Journal of Computer-Mediated Communication 5 (1): 0-0.

Searle, John R. 1969. Speech Acts. Cambridge University Press.

Söderholm, Pirjo. 2002. Svensk språk- och stilutveckling från 1865 till 1990 sådan den avspeglas i lärobokstexter och tidningsspråk. [Swedish Linguistic and Stylistic Development from 1865-1900 in the Light of Texts Appearing in Readers and Journalistic Language. Ph.D. Diss.] Akademisk avhandling. Helsingfors.

Weigand, Edda. 1999. "Misunderstanding: The Standard Case." Journal of Pragmatics 31 (6): 763-785.

Weigand, Edda. 2006. "Argumentation: The Mixed Game." Argumentation 20: 59-87. 
Weigand, Edda. 2009. Language as Dialogue: From Rules to Principles of Probability, ed. by Sebastian Feller. Netherlands/Amsterdam: Benjamins.

Weigand, Edda. 2010. Language as Dialogue. Intercultural Pragmatics 7 (3): 505-511.

Wenner, Lawrence A. (ed.). 1989. Media, Sports, \& Society. Newbury Park, Calif.: Sage.

Westin, Ingrid. 2008. Language Change in English Newspaper Editorials. Amsterdam: Rodopi.

\author{
Author's address \\ Barbro Lundin \\ University of Learning and Communication, Jönköping \\ Box 1026 \\ S-55111 Jönköping \\ SWEDEN \\ barbro.lundin@hlk.hj.se
}

\begin{abstract}
About the author
Barbro Lundin, Ph.D., senior lecturer of the Swedish language. Postgraduate studies at the University of Lund. Dissertation in 1988 on young children's production of subordinate clauses. Now committed to upper secondary school teacher training. Special fields of interest: newspaper langugage, syntactic tendencies in media language, sports journalism, students' writing capacities, young children's language development.
\end{abstract}

